\title{
Uroguanylin induces electroencephalographic spikes in rats
}

\author{
Teixeira ${ }^{a, \#}, M D A$., Nascimento ${ }^{b}, N R F .$, Fonteles $^{c, d}, M C$. and Vale ${ }^{a, d *}, O C$. \\ ${ }^{a}$ Biomedicine Institute, Clinical Research Unit, Pharmacology and Physiology Department, School of Medicine, \\ Federal University of Ceará, Fortaleza, CE, Brazil \\ ${ }^{b}$ Superior Institute of Biomedicine - ISCB and Faculty of Veterinary, State University of Ceará, Fortaleza, CE, Brazil \\ ${ }^{c}$ Mackenzie University, São Paulo, SP, Brazil \\ ${ }^{d}$ Clinical Medicine Department, Neurology, School of Medicine, Federal University of Ceará, Fortaleza, CE, Brazil \\ "Partial fullfillment of graduate degree in Pharmacology in 2003, Federal University of Ceará, Fortaleza, CE, Brazil \\ *e-mail: otonivale@gmail.com \\ Received February 14, 2012 - Accepted March 21, 2013 - Distributed August 31, 2013
}

(With 3 figures)

\begin{abstract}
Uroguanylin (UGN) is an endogenous peptide that acts on membrane-bound guanylate cyclase receptors of intestinal and renal cells increasing cGMP production and regulating electrolyte and water epithelial transport. Recent research works demonstrate the expression of this peptide and its receptor in the central nervous system. The current work was undertaken in order to evaluate modifications of electroencephalographic spectra (EEG) in anesthetized Wistar rats, submitted to intracisternal infusion of uroguanylin $(0.0125 \mathrm{nmoles} / \mathrm{min}$ or $0.04 \mathrm{nmoles} / \mathrm{min})$. The current observations demonstrate that $0.0125 \mathrm{nmoles} / \mathrm{min}$ and $0.04 \mathrm{nmoles} / \mathrm{min}$ intracisternal infusion of UGN significantly enhances amplitude and frequency of sharp waves and evoked spikes $(p=0.03)$. No statistical significance was observed on absolute alpha and theta spectra amplitude. The present data suggest that UGN acts on bioelectrogenesis of cortical cells by inducing hypersynchronic firing of neurons. This effect is blocked by nedocromil, suggesting that UGN acts by increasing the activity of chloride channels.
\end{abstract}

Keywords: neuroexcitatory response, brain spikes, neuronal depolarization.

\section{Uroguanilina induz potenciais em espiga no eletroencefalograma de ratos}

\section{Resumo}

A uroguanilina (UGN) é um peptídeo endógeno que age em receptores do tipo guanilato ciclase de membrana de células intestinais e renais aumentando a produção de GMPc e regulando o transporte epitelial de eletrólitos e água. Pesquisas recentes demonstraram a expressão deste peptídeo e de seus receptores no sistema nervosa central. $O$ presente trabalho foi realizado com objetivo de avaliar possíveis mudanças no espectro do eletroencefalograma (EEG) de ratos Wistar anestesiados, submetidos à infusão intracisternal de uroguanilina $(0.0125 \mathrm{nmoles} / \mathrm{min}$ or $0.04 \mathrm{nmoles} / \mathrm{min}$ ). Os resultados apresentados no corrente trabalho demonstram que a infusão intracisternal de ambas as doses de UGN aumenta significativamente a amplitude e frequência das espículas $(p=0.03)$. Não foram encontradas diferenças estatísticas na amplitude absoluta dos espectros alfa ou teta. Os dados apresentados neste trabalho mostram que a UGN age na bioeletrogênese de células corticais induzindo disparo hipersincrônico de neurônios. Este efeito é bloqueado por nedocromil, sugerindo que UGN atua pelo aumento de atividade de canais de cloreto.

Palavras-chave: neuroexcitação, cerebral spikes, despolarização neuronal.

\section{Introduction}

Guanylin and related peptides that activate transmembrane guanylate cyclase (GC) were first described over two decades ago. These peptides are similar to the heat-stable enterotoxin (STa) secreted mainly by some strains of enteric bacteria $E$. coli that cause traveler's diarrhea (Currie et al., 1992; Hamra et al., 1993). The first observations of functional receptors were described by Lima et al. (1992) in the perfused kidney. It is well established that these two peptides regulate salt and water ho- meostasis in the kidney (Fonteles et al., 1998) and in the intestine (Forte, 1999), through a pathway that could lead to an endocrine regulation between these two physiological systems. There is evidence of guanylin and uroguanylin receptors within the digestive, renal, cardiac, reproductive, immune-lymphoid organ systems and in the central nervous system (Forte et al., 2000; Fan et al., 1997). In those tissues, these peptides provide a pathway for paracrine and/or autocrine regulation of cellular functions via GMPc. Although a physiological role in the brain was yet to be demonstrated at the time, Schulz et al. 
(1992) obtained GC-C cDNA clones from guanylyl cyclase in the brain and D'Este et al. (2000) observed cell-specific localization of guanylin in the juxtaneural pars tuberalis adjacent to nerve endings and blood vessels of the hypothalamo-pituitary portal system and in gonadotrophic cells within the distal pars tuberalis and ventrolateral region of the pars distalis.

The membrane receptor GC-C is expressed on midbrain dopamine neurons and has a crucial role in regulating animal activity level and attention (Gong et al., 2011).

In addition, uroguanylin participates in an endocrine axis regulating feeding in mice (Valentino et al., 2011). In this system, prouroguanylin is converted to uroguanylin in the central nervous system, activates guanylyl cyclase $2 \mathrm{C}$ (GUCY2C) receptors in the brain to reduce food intake in mice.

Despite of evidences of an operating central guanylin-peptide system the possibility of activation of brain guanylin receptors were not probed to date.

Therefore, we have decided to probe the possible direct actions of uroguanylin in the brain.

\section{Materials and Methods}

The protocol of the present experiments was approved by the Ethical Committee for animal research of Federal University of Ceará, Brazil.

Male Wistar rats ( $n=6$ /group) weighing 220-270 g were anesthetized with intramuscular injection of xylazine and ketamine (10 and $50 \mathrm{mg} / \mathrm{kg} / \mathrm{BW}$, respectively). The access to the cistern magna in other to infuse uroguanylin was done according to the experimental method reported by Consiglio and Lucion (2000). Briefly, the skull was exposed by a median incision on the top of the head and two screws were implanted in it and fixed with dental cement. The external extremities of these screws were kept exposed in order to be attached to EEG electrodes. A guide cannula of $16 \mathrm{~mm}$ in length and $0.8 \mathrm{~mm}$ in diameter was implanted by means of a stereotaxic apparatus in order to contact the cisterna magna, according to the following parameters: Antero-posterior $(\mathrm{AP})=-2.7 \mathrm{~mm}$ (posterior to the interaural line), Vertical $(\mathrm{V})=-6.2 \mathrm{~mm}$ (below the dura-mater); Lateral $(\mathrm{L})=0$; angle $\left(\theta=31^{\circ}\right)$; superior incisive $=-3.2 \mathrm{~mm}$ under the interaural line. The cannula was then fixed with dental cement after its implantation. A 25-gauge scalp of $2 \mathrm{~mm}$ length longer than the guide cannula was used to collect CSF and to infuse guanylin or uroguanylin.

The EEG recordings were done three days after the implantation of the cannula. Each rat had its EEG recorded during $10 \mathrm{~min}$ before UGN $(0.0125 \mathrm{nmoles} / \mathrm{min}$ or $0.04 \mathrm{nmoles} / \mathrm{min}$ ) or saline intracisternal infusion and throughout the period of infusion (30 min), and $20 \mathrm{~min}$ after the end of infusion. In another experimental group the effect of UGN at the rate of $0.04 \mathrm{nmoles} / \mathrm{min}$ was probed after $10 \mathrm{~min}$ intracisternal injection of $50 \mu$ moles nedocromil (10 $\mu \mathrm{L}$ volume injection).
To enable the EEG recording, two active surface electrodes were attached to the two screws fixed in the bone of left and right parietal region of the skull (P3, left; $\mathrm{P} 4$, right). Two other active electrodes were implanted subcutaneously over left (F3) and right (F4) frontal regions. Two reference electrodes were attached to left (A1) and right (A2) ears. The ground electrode was also implanted subcutaneously in the rat nose. The acquisition system was purchased from EMSA ${ }^{\circledR}$ (Rio de Janeiro, Brazil) and was constituted by a pre-amplifier with adjustable time constants, an amplifier, a 12 bits analogdigital converter, a Pentium III microcomputer, and a software Braintech ${ }^{\circledR}$ (Rio de Janeiro - Brazil) for spectral analysis and wave amplitude studies. This software calculates the frequency components with precision of $0.35 \mathrm{~Hz}$.

The whole study consisted of three evaluation protocols of the EEGs obtained: a) evaluation of absolute mean amplitudes of alpha and theta EEG spectra; b) evaluation of the frequency of spikes during EEG examination of the animals; c) evaluation of mean absolute amplitudes of the spikes detected during EEG of the animals.

Before the infusion, $100 \mu \mathrm{L}$ of CSF were collected in order to assure that the tip of the scalp gauge was in the intracisternal space. The solutions of UGN were prepared in sterile physiological saline immediately before administration and the infusion was done by means of a pump (Braun Melsugen, Hamburg, Germany) connected to the scalp gauge inserted in the rat cisterna magna. Uroguanylin was kindly donated by Professor Leonard Forte from University of Missouri at Columbia (USA).

Parametric tests were used to compare treatment groups and internal controls; paired t-test was performed to evaluate significant differences of the mean absolute amplitudes of EEG spectra of frequencies, the frequency of spikes, and the spike mean absolute amplitude. To analyse dose-dependence of the significant differences, one-way ANOVA and Tukey test were adopted. The differences were considered significant when $\mathrm{p} \leq 0.05$.

\section{Results}

We have chosen theta and alpha amplitude spectra for absolute amplitude analysis because these spectra were dominant in the EEG of the animals studied. In Table 1 the mean absolute amplitude \pm standard error of the mean (SEM) of each of these two spectra registered on two different regions (F3 and F4) are presented. There was no significant mean absolute wave amplitude difference of the two frequency spectra between control (intracisternal saline infusion - SG) or with UGN ( $0.0125 \mathrm{nmoles} / \mathrm{min}$ or $0.04 \mathrm{nmoles} / \mathrm{min})$. The EEG registered during infusion was examined. The mean absolute amplitudes of alpha and theta espectra of EEG after infusion were also compared with those of controls with no statistical significant difference established (Table 1).

The qualitative aspects of the effects of UGN infusion observed in eletroencephalographic recordings are depicted in Figure 1. 
Table 1 - Effects of uroguanylin in the amplitude of alpha and theta spectra of EEG obtained from anesthetized Wistar rats.

\begin{tabular}{lccccc}
\hline Spectrum & Region & \multicolumn{3}{c}{ Absolute amplitude $(\mu \mathrm{V})$ : mean \pm SEM } \\
\cline { 3 - 5 } & & Control & $\begin{array}{c}\text { Uroguanylin } \\
\mathbf{( 0 . 0 1 2 5} \text { nmoles/min) }\end{array}$ & Control & $\begin{array}{c}\text { Uroguanylin } \\
(\mathbf{0 . 0 4} \text { nmoles/min) }\end{array}$ \\
\hline \multirow{2}{*}{ Alpha } & F3 & $139.3 \pm 18.6$ & $147.5 \pm 13.0$ & $138.0 \pm 11.9$ & $141.0 \pm 11.2$ \\
& F4 & $154.7 \pm 15.9$ & $170.0 \pm 23.8$ & $189.0 \pm 33.7$ & $189.0 \pm 46.3$ \\
\multirow{2}{*}{ Theta } & F3 & $152.5 \pm 34.7$ & $127.5 \pm 9.3$ & $174 \pm 10.1$ & $147 \pm 9.9$ \\
& F4 & $174.2 \pm 23.9$ & $152.5 \pm 9.8$ & $237 \pm 25.2$ & $198 \pm 42.7$ \\
\hline
\end{tabular}

Mean absolute amplitude of EEG alpha and theta spectra (values expressed as mean \pm SEM). These values were calculated from chosen free artifacts epochs from EEG registered during saline intracisternal infusion (control) and during intracisternal infusion of 0.0125 or $0.04 \mathrm{nmoles} / \mathrm{min}$ uroguanylin. Paired groups saline vs. peptide infusion period were considered in the evaluation. There are no statistical differences among groups.

The Figure $2 \mathrm{a}$ shows the frequency of spikes evaluated from the EEG of each group. Differences in the frequency of spikes were considered when comparisons were made between saline infusion and uroguanylin infusion. The control frequency of spikes (spikes/min) observed before $0.0125 \mathrm{nmoles} / \mathrm{min}$ infusion of UGN were $31.4 \pm 4.1$ and resulted in $45.6 \pm 5.5(69.7 \%$ increase, $\mathrm{p}<0.05 ; \mathrm{n}=6$ ) after $30 \mathrm{~min}$ infusion. Similarly, the infusion of 0.04 nmoles/min UGN increased the frequency of spikes from $27.8 \pm 4.1$ to $55.3 \pm 2.1(98.9 \%$ increase; $\mathrm{p}<0.05 ; \mathrm{n}=6$ ).

When, absolute mean amplitudes of spikes were analyzed (Figure 2b), an increase of the spike amplitudes was observed during and after uroguanylin ( $0.0125 \mathrm{nmoles} / \mathrm{min}$ or $0.04 \mathrm{nmoles} / \mathrm{min})$ intracisternal infusion. The mean amplitude of spikes was also increased by this peptide in both infusion rates. The amplitude of spikes after $0.0125 \mathrm{nmoles} / \mathrm{min}$ UGN was $48.9 \pm$ $3.3 \mu \mathrm{V}$ compared with $37.2 \pm 4.6 \mu \mathrm{V}$ registered in control rats. The higher rate of infusion $(0.04 \mathrm{nmoles} / \mathrm{min})$ produced an increase in mean amplitude that varied from control values of $38.4 \pm 1.9$ to $55.2 \pm 4.7 \mu \mathrm{V}$ (43.8\% increase; $\mathrm{p}<0.05 ; \mathrm{n}=6$ ).
The effect of 0.04 nmoles/min UGN infusion on the frequency of spikes was completely blocked by previous administration of nedocromil. The values obtained in an unpaired control group were $32.6 \pm 1.9$ spikes $/ \mathrm{min}$ before UGN infusion, compared to $63.5 \pm 4.7$ spikes $/ \mathrm{min}$ (94.8\% increase; $\mathrm{p}<0.01 ; \mathrm{n}=6$ ) achieved after infusion. In the group treated with nedocromil ( $50 \mu$ moles, $10 \mathrm{~min}$ before UGN challenge) the control frequency of spikes was $31.6 \pm 4.6$ compared to $34.2 \pm 3.6$ spikes $/ \mathrm{min}$ $(\mathrm{p}>0.05 ; \mathrm{n}=6)$ (Figure 3$)$.

\section{Discussion}

After the demonstration that guanylin and uroguanylin peptides stimulate membrane guanylate cyclases and regulate intestinal and renal functions via cGMP, other regions outside the intestinal-renal axis became targets for investigation, seeking for other activities of these peptides.

An endocrine axis regulating feeding in mice was recently described for UGN that could have clinical implications for the control of appetite, obesity and metabolic syndrome (Valentino et al., 2011).
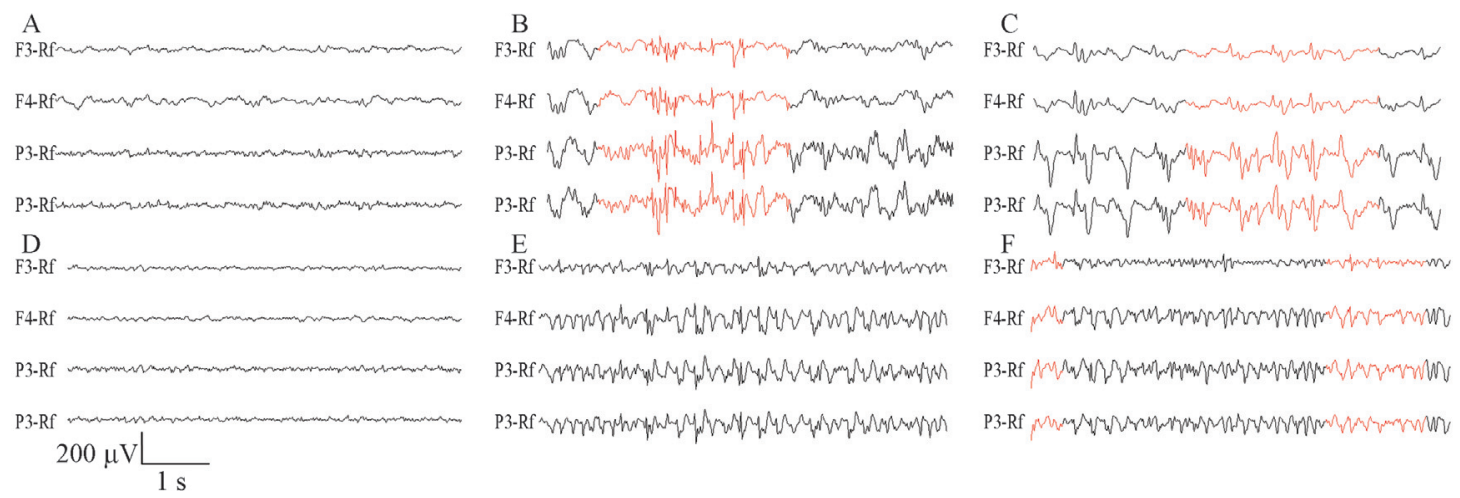

Figure 1 - Representative electroencephalographic recordings of anaesthetized Wystar rats depicting the observations of control (A and D); and uroguanylin infusion at 0.0125 (B) or $0.04 \mathrm{nmoles} / \mathrm{min}$ rate (E). C and F represent the EEG pattern twenty minutes after cessation of uroguanylin infusion $(0.0125$ and $0.04 \mathrm{nmoles} / \mathrm{min}$, respectively). Note that the uroguanylininduced effects are not reversible, even in the lower dose, during the 20-minute post infusional period (C and F). 

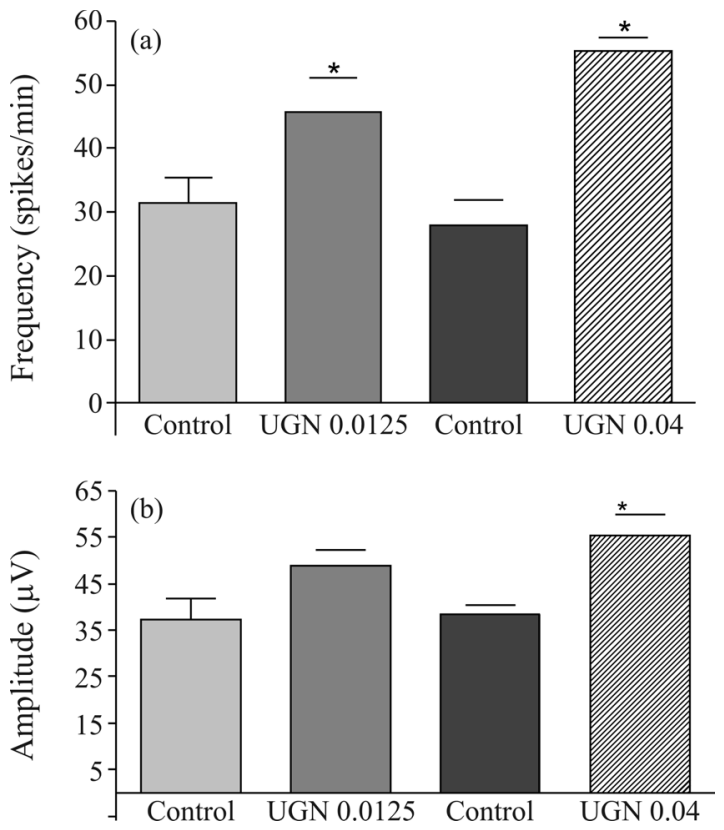

Figure 2 - Effects of uroguanylin (0.0125 and $0.04 \mathrm{nmoles} / \mathrm{min}$ ) infusion in the cisterna magna on the frequency (a) and amplitude (b) of spikes recorded with electrodes implanted in the frontal region (F3-F4). ${ }^{*} p<0.05$, ANOVA with Tukey as the post hoc test. The data are expressed as mean \pm SEM of six animals.

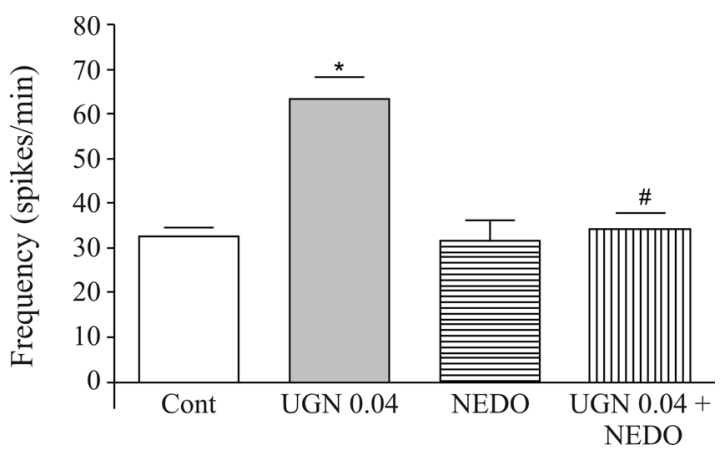

Figure 3 - Effects of uroguanylin (0.04 nmoles/min) infusion in the cisterna magna on the frequency of spikes recorded with electrodes implanted in the frontal region (F3-F4) both in the absence or presence of nedocromil ( $50 \mu$ moles in bolus $10 \mathrm{~min}$ before). ${ }^{*} \mathrm{p}<0.05$, ANOVA followed by Tukey as the post hoc test vs. control (CONT). $\# \mathrm{p}<0.05$, ANOVA followed by Tukey as the post hoc test vs. UGN alone. The data are expressed as mean \pm SEM of six experiments.

Our results demonstrated no statistical significant differences in the mean absolute amplitudes of alpha and theta spectra induced by intracisternal infusion of uroguanylin saline solutions at different concentrations. This indicates that, at least in our experimental model, uroguanylin do not modify dopaminergic thalamo-cortical action (alpha spectrum) or GABAergic activity of reticu- laris nucleus on thalamic neurons (theta spectrum) (John, 2002).

As uroguanylin was shown to change $\mathrm{K}^{+}$-channels (Amorim et al., 2006) and chloride channels conductance through the plasma membrane, we concentrated our attention on spike potentials, involving not only spikes per se, but also sharp waves. A spike is a transient potential, clearly distinguished from the background activity, with pointed peak at conventional paper speed and with a duration that varies from 20 to under $70 \mathrm{~ms}$. Sharp waves are also transient, clearly distinguished from background activity, with pointed peak and a duration of 70-200 ms (IFSECN, 1974). Both spike and sharp waves are caused by hypersynchronous events due to excessive simultaneous neuronal discharge (Niedermeyer, 1999).

We verified that intracisternal infusion of uroguanylin induced an increase of the frequency of spikes and sharp waves/minute during EEG registration. These facts made us to suppose that uroguanylin facilitate hypersyncronous events due to excessive simultaneous neuronal discharge. Sharp waves and spikes were synchronous in all channels of both sides of EEG registration, suggesting that they represent multiple unit recordings involving cortical and subcortical structures, such as specific or non-specific thalamo-cortical diffusely distributed ensembles. Sharp waves and spike waves provoked by intracisternal infusion of UGN could reflect its synchronic neural excitatory or neural disinhibition activities.

Uroguanylin was previously shown to induce either GC-independent (in rat principal cells of the cortical collecting duct) or cGMP-dependent (in mammalian olfactory neurons) depolarization (Sindic et al., 2005; Leinders-Zufall et al., 2007). This later study has showed by both patch-clamp and confocal $\mathrm{Ca}^{2+}$-imaging studies that uroguanylin evokes an excitatory, cGMP-dependent signaling cascade that increases intracellular $\mathrm{Ca}^{2+}$ and action potential firing. Recently it was demonstrated that uroguanylin potentiates excitatory responses mediated by either glutamate or acetylcholine receptors via a cGMP-dependent protein kinase (PKG) pathway (Gong et al., 2011). These mechanisms were not investigated in the present work and are possibilities for future investigation in this field.

In addition, this effect of uroguanylin was not reversible during the $20 \mathrm{~min}$ post infusional period. This phenomenon is similar to the effects observed in the kidney where the diuretic and natriuretic effect lasted for more than 90 min (Fonteles et al., 1998).

Otherwise, the acute form of glutamate neurotoxicity has been associated to depolarization-induced influx of $\mathrm{Cl}^{-}$(Rothman et al., 1985) and a blockade of swelling-activated chloride channels was shown to be cerebroprotective and to reduce levels of ischemia-induced efflux of aspartate, glutamate, taurine and phosphoethanolamine from cerebral cortical cells (Phillis et al., 1998). The process of cell volume regulation is essentially linked to the volume-sensitive $\mathrm{Cl}^{-}$current $\left(\mathrm{I}_{\mathrm{Cl}(\mathrm{vol})}\right)$ 
(Heinke et al., 1995) and these channels are sensitive to nedocromil (Gschwentner et al., 1996).

Therefore, we conclude that the neuronal hypersynchronic firing of neurons evoked by uroguanylin is related to a direct effect on chloride channels as discussed above since it is blocked by nedocromil. The signaling pathways associated to this phenomenon have not been completely known at this point.

\section{Acknowledgments}

The authors would like to thank Silvia Maria Freire França for skillful technical assistance and Conselho Nacional de Desenvolvimento Científico e Tecnológico (CNPq) and Fundação Cearense de Apoio a Pesquisa (FUNCAP) for the financial support.

\section{References}

AMORIM JB, MUSA-AZIZ R, LESSA LM, MALNIC G, and FONTELES MC., 2006. Effect of uroguanylin on potassium and bicarbonate transport in rat renal tubules. Canadian Journal of Physiology and Pharmacology, vol. 84, p. $1003-1010$

CURRIE, MG., FOK, KF.,KATO, J.,MOORE, RJ.,HAMRA, FK.,DUFFIN, KL. and SMITH, CE., 1992. Guanylin: an endogenous activator of intestinal guanylate cyclase. Proceedings of the National Academy of Sciences of the United States of America, vol. 89, no. 3, p. 947-951.

CONSIGLIO, AR. and LUCION, AB., 2000. Technique for collecting cerebrospinal fluid in the cisterna magna of non-anesthetized rats. Brain Research Protocols, vol. 5, p. 109-14.

D'ESTE, L., KULAKSIZ, H., RAUSCH, U., VACCARO, R., WENGER, T., YOSHIMITSU TOKUNAGA, RENDA, TG. and CETIN, Y., 2000. Expression of guanylin in "pars tuberalis-specific cells" and gonadotrophs of rat adenohypophysis. Proceedings of the National Academy of Sciences of the United States of America, vol. 97, p. 1131-1136.

FONTELES, MC., GREENBERG, RN., MONTEIRO, HSA., CURRIE, MG. and FORTE, LR., 1998. Natriuretic and kaliuretic activities of guanylin and uroguanylin in the isolated perfused rat kidney. American Journal of Physiology, vol. 275, p. F191-F197.

FORTE LR., 1999. Guanylin regulatory peptides: structures, biological activities mediated by cyclic GMP and pathobiology. Regulatory Peptides, vol. 81, p. 25-39.

FORTE, LR., LONDON, RM., KRAUSE, WJ. and FREEMAN, RH., 2000. Mechanisms of guanylin action via cyclic GMP in the kidney. Annual Review of Physiology, vol. 62, p. 673-695.

GSCHWENTNERA, M., SUSANNAA, A., SCHMARDAA, A., LAICHA, A., NAGLA, UO., ELLEMUNTERB, H., DEETJENA, P., FRICKC, J. and PAULMICHLA, M., 1996. ICln: a chloride channel paramount for cell volume regulation. Journal of Allergy and Clinical Immunology, vol. 98, p. S98-S101.

HAMRA, FK., FORTE, LR., EBER, SL., PIDHORODECKYJ, NV., KRAUSE, WJ., FREEMAN, RH., CHIN, DT., TOMPKINS, JA., FOK, KF. and SMITH, CE., 1993. Uroguanylin: structure and activity of a second endoge- nous peptide that stimulates intestinal guanylate cyclase. Proceedings of the National Academy of Sciences of the United States of America; vol. 90, no. 22, p. 10464-10468.

HEINKE, S., SZÜCS, G., NORRIS, A., DROOGMANS, G. and NILIUS, B., 1995. Inhibition of volume-activated chloride currents in endothelial cells by chromones. British Journal of Pharmacology, vol. 115, p. 1393-1398.

IFSECN, 1974. A glossary of terms commonly used by clinical electroencephalographers. Electroencephalography and Clinical Neurophysiology, vol. 37, p. 538-548.

JOHN, ER., 2002. The neurophysics of consciousness. Brain Research Reviews, vol. 39, p. 1-28.

LEINDERS-ZUFALL, T., COCKERHAM, RE., MICHALAKIS, S., BIEL, M., GARBERS, DL., REED, RR., ZUFALL, F. and MUNGER, SD., 2007. Contribution of the receptor guanylyl cyclase GC-D to chemosensory function in the olfactory epithelium. Proceedings of the $\mathrm{Na}$ tional Academy of Sciences of the United States of America, vol. 104 , no. 36 , p. 14507-14512.

LIMA, AA., MONTEIRO, HS. and FONTELES, MC., 1992. Effects of thermostable Escherichia coli enterotoxin peptide on the isolated rat kidney. Brazilian Journal of Medical and Biological Research, vol. 25, no. 6, p. 633-636.

NIEDERMEYER, E.,1999. Abnormal EEG patterns: epileptic and paroxysmal. In NIEDERMEYER, E. AND SILVA, FLD., (Eds.). Electroencephalography: Basic Principles, Clinical Applications, and Related Fields. Baltimore: Lippincott, Williams \& Wilkins. pp. 235-260.

PHILLIS, JW., SONG, D. and O'REGAN, MH., 1998. Tamoxifen, a chloride channel blocker, reduces glutamate and aspartate release from the ischemic cerebral cortex. Brain research, vol. 780, no. 2, p.352-355.

RONG GONG, CHENG DING, JI HU, YAO LU, FEI LIU, MANN, E., FUQIANG XU, COHEN, MB., and MINMIN LUO, 2011. Role for the membrane receptor guanylyl cyclase-C in attention deficiency and hyperactive behavior. Science, vol. 333, no. 6049, p. 1642-1646.

ROTHMAN, DL., BEHAR, KL., HETHERINGTON, HP., DEN HOLLANDER, JA., BENDALL, MR., PETROFF, OA., and SHULMAN, RG., 1985. 1H-Observe/13Cdecouple spectroscopic measurements of lactate and glutamate in the rat brain in vivo. Proceedings of the National Academy of Sciences of the United States of America, vol. 82, no. 6 p. 1633-1637.

SCHULZ, S., CHISTMAN, TD., and GARBERS, DL.,1992. Cloning and expression of guanylin. Its existence in various mammalian tissues. The Journal of Biological Chemistry, vol. 267, p. 16019-16021.

SINDIC, A., VELIC, A., BASOGLU, C., HIRSCH, JR., EDEMIR, B., KUHN, M., and SCHLATTER, E., 2005. Uroguanylin and guanylin regulate transport of mouse cortical collecting duct independent of guanylate cyclase C. Kidney International, vol. 68, no. 3 p. 1008-1017.

VALENTINO, MA., LIN, JE., SNOOK, AE., LI, P., KIM, GW., MARSZALOWICZ, G., MAGEE, MS., HYSLOP, T., SCHULZ, S. and WALDMAN, SA., 2011. A uroguanylin-GUCY2C endocrine axis regulate feeding in mice. The Journal of Clinical Investigation, vol. 121, no. 9, p. 3578-3588.

XIAOHUI FAN, YUAN WANG, LONDON, RM., EBER, SL., KRAUSE, WJ., FREEMAN, RH. and FORTE, LR., 1997. Signaling pathways for guanylin and uroguanylin in the digestive, renal, central nervous, reproductive, and lymphoid systems. Endocrinology, vol. 138, no. 11, p. 4636-4648. 